Soviet science and technology

\section{Andropov has his say}

The Soviet Union will spend 25,500 million rubles on scientific and technological research next year - an increase of 6.2 per cent on 1982. The publication of actual investment figures is somewhat rare in the Soviet media, which prefer to cite increases in percentages only (often referring to inaccessible data-bases). The announcement of this increase which in real terms represents a rise of some four to five per cent, since inflation in the Soviet Union is running at between one and two per cent annually - was made in a Pravda editorial (a traditional Soviet method of announcing a new policy drive) dealing with the speech of Party Secretary Yurii Andropov at last month's plenum of the Central Committee of the Communist Party of the Soviet Union.

According to Mr Andropov, the "great reserves" available to the Soviet Union need to be used "more actively and more consistently". This is basically a reiteration of the Brezhnev policy of modernizing industry by high-priority implementation of research results in industry. This policy, Mr Andropov said, would be continued with even greater impetus - evoking from Academician Anatolii Aleksandrov, president of the Academy of Sciences, the rejoinder that if research results were not being implemented on schedule it was not the scientists but the production ministries which were at fault.

Mr Andropov, however, has some ideas of his own as to how this policy should be pursued. Already the Academy of Sciences carries major responsibility for coordinating the research programmes launched to meet the specific needs of Soviet industry and agriculture. Now, it appears, in addition to producing new equipment and "front-ranking work methods", the academy is set to take on a troubleshooting role. Together with the State Committee for Science and Technology and the relevant production ministries, it will be expected to "pinpoint and eliminate" the difficulties hindering technical progress. This approach could be of considerable importance for research planning.

During the past ten years, there has been emphasis on the establishment of local "science centres" (usually created by linking existing institutes in the locality), which were intended to serve the research needs of local industry, frequently on a direct contractual basis. The initiative was normally left to the industrial side, which identified production problems and then sought scientists' help to solve them. The new procedure suggests that scientists will now be expected to identify problems as well as solve them - a procedure which would not necessarily appeal to all enterprise directors. Retooling and redesigning of the production line is a

nightmare for Soviet management, since the regular quarterly, annual and quinquennial targets make no allowances for temporary shutdowns. A zealous scientist urging such a closure in the name of long-term improved efficiency might

\title{
Nuclear waste disposal
}

\section{Synroc presses on in Australia}

The Synroc programme - Australia's synthetic rock alternative to glass for the disposal of highly active nuclear waste - is about to move up a few gears with the construction of a cut-price, "commercialscale" Synroc plant 20 miles south-west of Sydney. The plant, at the Lucas Heights Research Laboratories of the Australian Atomic Energy Commission (AAEC), will be big enough to cope - in principle with 600-900 tons of spent fuel a year. But in practice it will not see a jot of nuclear waste.

The objective, according to Dr Keith Reeve, leader of the Synroc project at AAEC, is nevertheless to prove that Synroc

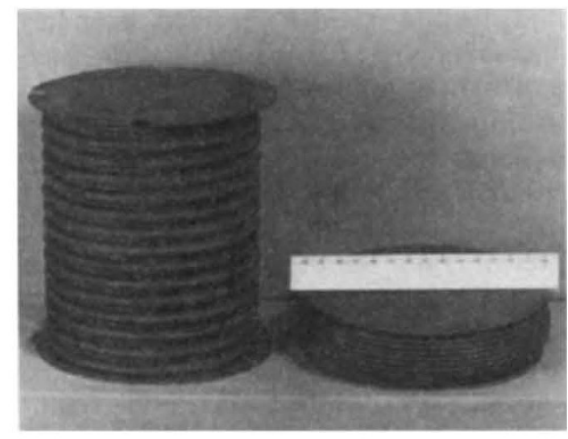

A recent $30-k g$ block of Synroc compressed using the uniaxial bellows hot pressing technique. Primary minerals (and waste) are sealed in evacuated stainless steel bellows, and pressed and heated without side supports. The resulting blocks would then be sealed in a larger can.

is a practical alternative to glass. Tenders closed last week for contract management of the detailed design work, and, says Reeve, the successful bidder is likely to have considerable experience of nuclear plant - for AAEC and the Australian National University (ANU), which is also involved in the project, wish to build a plant which, although non-radioactive, is compact, easily maintained, and demonstrates that active Synroc could be made safely.

Cost precluded the construction of a fully active plant, according to Professor Ted Ringwood, inventor of Synroc and ANU representative on the demonstration plant project. A remotely-controlled active plant might have cost "hundreds of millions of dollars" (A\$1.7 $=£ 1)$, says Ringwood "of the same order as a well run foul of a director eager to meet his immediate target figures.

Perhaps to overcome such frictions, the recent plenum urged the importance of material incentives for those involved in modernization projects. People who "boldly go for the introduction of new technology", it noted, should not find themselves placed in a "disadvantageous situation".

Vera Rich glassification plant"'. But AAEC and ANU have only $A \$ 2.7$ million to spend, the amount of a government grant for the project, plus staff support from AAEC and ANU. A little over A\$1 million was released in August, with the rest promised over the next two years, for construction in 1983-84 and operation in 1984-85. "I blow hot and cold on whether these dates are optimistic or pessimistic", says Reeve.

Whenever the plant is ready, it will make Synroc-C, which consists of 60 per cent titanium dioxide, with an admixture of barium oxide, calcium oxide, zirconia and alumina; these react at $1,100-1,170^{\circ} \mathrm{C}$ and 100-400 atmospheres pressure to create three mineral phases related to perovskite, hollandite and zirconalite. These phases can absorb up to 20 per cent weight of highly active waste oxides, according to Reeves.

At AAEC in Lucas Heights, experiments have concentrated on producing the Synroc in large-scale blocks, rising from a few granules in 1979 to $30-\mathrm{kg}$ hot pressings by the end of 1981. The Synroc itself is able to retain foreign elements much better than glass, the Synroc team maintains; it is also 59 per cent denser and can withstand higher temperatures.

The apparent weakness of the Synroc programme, however, has been the relative lack of work on active Synroc - Synroc actually containing nuclear waste. "We're sensitive to that criticism", says Reeves, and in fact next year Reeves plans a "twoline" radioactive test programme. One will involve neutron-irradiated uranium oxide (to stimulate fission products) in small $(1 / 2-1 \mathrm{~cm}$ diameter) Synroc samples, on which leach tests will be done. The oxide will be fresh from irradiation, Reeves stresses, unlike spent fuel which has been cooled for a few years, and it will be possible to reproduce in two years the total beta-ray dose expected in a piece of active, waste-containing Synroc over its lifetime. The samples will then be subjected to leach tests. Alpha irradiation will also be simulated with neutrons.

And in the second line of radioactive tests, Synroc will be made in a glove box with "trace" levels of actinides neptunium, plutonium, americium and curium. The work will start in June.

Robert Walgate 